\title{
消 息
}

\section{“亚太地区蛋白质学会第三届学术会议”暨 “中英双边蛋白质科学研讨会”在上海大学召开}

2011 年 5 月 6 日, 由“亚太地区蛋白质学会(Asia Pacific Protein Association, APPA)和国际蛋白质学会(The Protein Society)主办、中国生化学会蛋白质专业委员会(The Chinese Protein Society)承办的“亚太地区蛋白质学 会第三届学术会议”暨“第三届全国跨学科蛋白质研究学术讨论会”在上海大学开幕.

来自美国、英国、德国、日本、韩国、澳大利亚、印度、中国等 30 多个国家和地区的近 600 位代表参加 了会议, 其中包括国际蛋白质学会前任主席 Arthur G. Palmer III 教授、英国生物化学学会主席 Tom Blundell 爵士、Journal of Molecular Biology 主编 Peter Wright 教授、Biochemical Journal 主编 Peter Shepherd 教授、亚 太地区蛋白质学会主席 Yuji Goto 教授, 以及日本、韩国、澳大利亚、泰国等国家的蛋白质学会主席等. 中国 生物化学与分子生物学学会蛋白质专业委员会主任王志珍院士、中国生物化学与分子生物学学会理事长王志 新院士、中国生物物理学会理事长饶子和院士、教育部高等学校生物科学与工程教学指导委员会主任施蕴渝 院士及张友尚院士、王恩多院士、隋森芳院士、科技部基础司司长张先恩教授等国内众多著名学者出席了会 议. 会议得到国家自然科学基金委员会、科技部、中国科学院、上海市人民政府以及上海大学的大力支持. 此 次会议是中国乃至世界科学界的一次重大盛会, 为科研工作者, 特别是青年学者提供了一次难得的学习机会.

会议开幕式由大会秘书长、中国生物化学与分子生物学学会蛋白质专业委员会主任委员昌增益教授主持, 大会组委会主席王志珍院士致开幕词, Yuji Goto 教授、饶子和院士、张先恩教授、上海大学党委书记于信汇 教授分别在开幕式上发言.

大会主要报告有 6 个: 美国 Scripps 研究所 Peter Wright 教授、英国剑桥大学 Tom Blundell 教授、日本东 京都市医学科学研究所 Keiji Tanaka 教授、哈佛大学施扬(Yang Shi)教授、德国马普生物化学研究所 Wolfgang Baumeister 教授及哈佛大学谢晓亮(Sunney Xiaoliang Xie)教授报告, 介绍和展示了世界上最新的蛋白质科学研 究进展及新方法、新技术. 专题报告 45 场, 内容涉及蛋白质科学的各个领域. 会议期间, 代表们就蛋白质科学 研究的热点问题: 蛋白质生物合成, 蛋白质折叠、结构与动态, 蛋白质修饰和相互作用, 蛋白质设计与工艺, 蛋白质定量检测与单分子研究, 蛋白质与疾病及药物设计, 蛋白质组学, 蛋白质交叉研究等 10 个专题进行了 深入而广泛的讨论. 会议还从提交的摘要中选出 15 位报告人, 并设优秀报告奖和优秀墙报奖, 以鼓励在蛋白 质科学研究方面取得优异成绩的青年学者, 为大家提供了一个良好的交流平台.

为庆祝英国生化学会成立 100 周年, 英国生化学会和中国蛋白质专业委员会联合举办的“中英双边蛋白质 科学研讨会”于 5 月 5 7 日在上海大学举行. 组委会共同主席王志珍院士和 Tom Blundell 爵士、上海大学党委 副书记、常务副校长周哲玮教授分别在开幕式上致词. 此次会议加强了中英蛋白质科学工作者之间的交流与 合作.

5 月 5 日, 在上海大学生命科学学院召开了中国生物化学与分子生物学学会蛋白质专业委员会新一届委员 会议, 与会的近 40 位委员对中国蛋白质科学领域的未来学术交流展开了热烈地讨论, 并确定第四届全国跨学 科蛋白质研讨会于 2013 年在安徽召开. 在上海大学召开的亚太地区蛋白质学会(APPA)执委会上, 中国生物化 学与分子生物学会蛋白质专业委员会新一任主任委员、国际蛋白质学会执委昌增益教授当选为新一任亚太地 区蛋白质学会主席. 